\title{
From the Editor:
}

Slavic Review publishes letters to the editor with educational or research merit. Where the letter concerns a publication in Slavic Review, the author of the publication will be offered an opportunity to respond. Space limitations dictate that comment regarding a book review should be limited to one paragraph; comment on an article should not exceed 750 to 1,000 words. The editor encourages writers to refrain from ad hominem discourse.

D.P.K.

\section{To the Editor:}

The article by Klaus-Peter Friedrich, "Collaboration in a 'Land without a Quisling': Patterns of Cooperation with the Nazi German Occupation Regime in Poland during World War II" (Slavic Review 64, no. 4) addresses an important topic. The author's scholarly apparatus gives the impression of the proverbial German Gründlichkeit, yet in the final analysis, Friedrich's handling of this question raises doubts about his objectivity and methodology.

In the first place, I miss a clear definition of collaboration. Calling it a social and ideological phenomenon is too vague. A much more satisfactory definition was provided by one of the leaders of the Polish underground: "Voluntary cooperation with the enemy to the detriment of the country or fellow citizens" (Stefan Korbonski, The Polish Underground State: A Guide to the Underground, 1939-1945, 1978, 140).

Friedrich seems to try so hard to make the point that "collaboration" was not a marginal phenomenon that he omits or downplays different views. He asserts (on what grounds?) that Jan T. Gross's book on the General Gouvernement, which he cites several times, has been largely ignored by Polish historiography. He mentions the article by Bernard Wiaderny as proof of Polish politicians' attempted offers of collaboration, but seems unaware of the discussion that followed it (Zeszyty Historyczne, no. 143 [2003]: 21534 and no. 144 [2003]: 232) and that brought out Wiaderny's many flaws. One looks in vain for any reference to another serious debate among historians: "Kolaboracja i historia," Arcana, no. 51/52 [2003]: 13-69. Similarly, in his several mentions of Jedwabne, Friedrich seems only to be familiar with Gross's book on the subject, but not the huge two-volume collection of studies and documents entitled Wokót Jedvabmego, edited by Paweł Machcewicz and Krzysztof Persak (2002). Finally, one wonders why the major bookchronicle by a prominent member of the underground Żegota (which helped the Jews), Władysław Bartoszewski, 1859 Dni Warszauny (1974) is ignored.

I wish that Friedrich who cites so many sources would also have stressed more clearly the significance of the date of a given publication. Given Polish conditions, it makes quite a difference when a book or article was published. The reader may not be fully aware of this.

As I said at the beginning of this letter, I fear that Friedrich's presentation is not balanced or even-handed. When he speaks of "collaboration" by the Polish clergy he does not mention (even in a footnote) the large number of priests who perished at Nazi hands. Is it really useful to give estimates of "collaborators" that range from 7,000 to 1 million rather than admit that one does not know and that it depends on what is meant by collaboration? And when speaking of the number of Jews rescued-and it is not clear to me how Friedrich arrived at his final figure-should one not also speculate how many Poles had to be involved to save one Jew? John Connelly makes this point in his comments in the same issue ("Why the Poles Collaborated So Little-And Why That Is No Reason for Nationalist Hubris," 780). And let us recall once again that aiding Jews was punishable by death only in Poland and in the occupied parts of the USSR. Last but not least, if "collab- 
oration" is understood so broadly, why does Friedrich ignore Jewish "collaborators"-the Jewish police in the ghettos, for instance?

To conclude, I fully concur that drawing attention to and analyzing myths is an important task of the historian. So is overcoming "mental predispositions," but I am not sure that Friedrich has overcome his own.

Piotr Wandycz Yale University

To the Editor:

It is good that Slavic Review (64, no. 4) published the collection of articles in "Forum: On Collaboration in Poland and the Soviet Union during World War II," but it is a pity that the treatment of the Poles is generally disappointing, especially in Karl-Peter Friedrich's article, "Collaboration in a 'Land without a Quisling': Patterns of Cooperation with the Nazi German Occupation Regime in Poland during World War II." Friedrich's thesis is not new: that the Poles helped the Germans to exterminate the Polish Jews, either directly or through indifference to their fate. It is unlikely that there will ever be a balanced consensus - especially between Poles and Jews - on the subject of Polish attitudes toward the Jewish Holocaust in German-occupied Poland. Friedrich's article, however, is not only one-sided but also has some strange omissions. What is missing here is the context of German terror, which the Poles had to face every day, and the natural urge not to run risks in order to survive. So much the greater was the courage required to hide and feed those Jews who were outside the ghetto, as was done by members of the underground organization to help the Jews, Żegota, though not only by them. As for the number of Jewish survivors in Poland, whom Friedrich estimates at no more than 15,000 at war's end (745), Lucjan Dobroszycki's detailed study based on Jewish records shows that registered Jewish survivors at the end of 1945 , numbered 99,881, of whom 18,285 were on German territory (Survivors of the Holocaust in Poland: A Portrait Based on Jewish Community Records 1944-1947, 1994, 83). This was before the influx of Jewish survivors from the USSR, who numbered between 150,000 and 200,000 .

The title of John Connelly's article suggests that Poles had no opportunity to collaborate, so they have no grounds for national pride in their wartime resistance ("Why the Poles Collaborated So Little-And Why That Is No Reason for Nationalist Hubris"). Indeed, given Nazi terror and Adolf Hitler's refusal to consider any kind of political partnership, the Poles had no room to engage in such activity. Does that mean, however, that they had no option but to resist? In theory, their leaders could have chosen passive resistance, but this was ruled out by both Polish tradition and their own participation in fighting for Poland's independence from 1914 to 1921 . Furthermore, the decision to fight was made before German policy was clear to all, and the Poles have good reason to be proud of their "Underground State" and its Armia Krajowa (Home Army).

In his generally balanced article, Connelly demolishes some of Friedrich's extreme contentions and notes that even if the Poles had seen the Jews as neighbors (that is, helped them as they helped other Poles), the Jewish survival rate would only have improved by 5 percent (780). But at the same time, Connelly also condemns "the megalomania of Polish nationalism" (772). If we look at other countries, however-as he encourages us to do (781) - we can see that each country tends to idealize its resistance to the Germans. Moreover, Connelly rightly states that each resistance movement must be seen in its historic context. One might add that this also applies to how national historical memory is shaped. In communist Poland, the official historiography of wartime resistance to the Germans lauded the communists, who represented only a tiny percentage of the national movement, while condemning as "fascist" the anti-German and anticommunist Armia Krajowa. (At the same time, nothing could be written about the Soviets' brutal oppression of the Poles in former eastern Poland from 1939 to 1941.) It is not surprising, therefore, that the Armia Krajowa was idealized in popular memory, and then lauded in both popular and academic historiography after the collapse of communism in Poland in summer 1989. Dissenting voices were also heard, however, especially on the Armia Krajowa leadership's decision to carry out the Warsaw Uprising against the Germans. This uprising lasted from 1 August to 2 October 1944 and led to wholesale destruction and great loss of life, as the Red 